\title{
Peran Dan Fungsi Pemerintah Dalam Penanggulangan Kerusakan Lingkungan
}

\author{
Muharuddin \\ Fakultas Hukum, Universitas Muhammadiyah Sorong \\ Email : amuharuddin@gmail.com
}

\begin{abstract}
Abstrak
Secara umum wilayah pesisir didefinisikan sebagai daerah pertemuan antara darat dan laut; kearah darat wilayah pesisir meliputi bagian daratan baik kering maupun terendam air, yang masih dipengaruhi oleh sifat-sifat laut seperti pasang surut, angin laut, dan perembesan air asin; sedangkan kearah laut mencakup bagian laut yang masih dipengaruhi oleh proses-proses alami yang terjadi di darat seperti sedimentasi dan aliran air tawar, maupun yang disebabkan oleh kegiatan manusia di darat seperti penggundulan hutan dan pencemaran.

Provinsi Papua Barat khususnya Kota Sorong merupakan salah satu daerah di Indonesia yang memiliki potensi pesisir dan kelautan yang sangat besar. Garis pantainya yang memiliki banyak potensi pesisir dan kelautan yang bisa dimanfaatkan. Keberadaan terumbu karang, hutan mangrove, serta keanekaragaman flora dan fauna laut merupakan potensi yang memiliki nilai ekonomi yang menjanjikan, baik di bidang produksi maupun di bidang pariwisata. Saat ini ekosistem pantai terancam kelestariannya terutama oleh kegiatan manusia. Sumber daya pantai merupakan anugerah alam yang sangat berharga bagi mahluk hidup yang perlu dikelola dan dikembangkan secara baik untuk kepentingan saat ini dan dimasa yang akan datang. Untuk tetap menjaga potensi sumber daya pesisir Kota sorong, maka diperlukan suatu pengelolaan yang dilakukan secara terpadu dan berkesinambungan agar sumber daya yang ada tersebut tetap terjaga.
\end{abstract}

Kata Kunci : Hukum Lingkungan, Konservasi Ekosistem Sumber Daya Hayati, Hukum Laut

\section{PENDAHULUAN}

Indonesia merupakan Negara Kepulauan dengan jumlah pulau yang mencapai 17.508 dan panjang garis pantai kurang lebih $81.000 \mathrm{Km}$ (DKP, 2008). Keadaan ini menyebabkan kawasan pesisir menjadi andalan sumber pendapatan masyarakat Indonesia. Secara umum, wilayah pesisir dapat didefenisikan sebagai wilayah pertemuan antara ekosistem darat, ekosistem laut dan ekosistem udara yang saling bertemu dalam suatu keseimbangan yang rentan.

Menurut Kay dan Alder pesisir adalah wilayah yang unik, karena dalam konteks bentang alam, wilayah pesisir merupakan tempat bertemunya daratan dan lautan. Lebih jauh lagi, wilayah pesisir merupakan wilayah yang penting ditinjau dari berbagai sudut pandang perencanaan dan pengelolaan. Departemen Kelauatan dan Perikanan dalam rancangan Undangundang Pengelolaan Wilayah Pesisir Terpadu mendefenisikan wilayah pesisir sebagai kawasan peralihan yang menghubungkan ekosistem darat dan ekosistem laut yang terletak antara batas sempadan kea rah darat sejauh pasang tertinggi dan ke arah laut sejauh pengaruh aktivitas dari daratan. Wilayah pesisir memiliki nilai ekonomi tinggi, namun terancam keberlanjutannya. Dengan potensi yang unik dan bernilai ekonomi tadi maka wilayah pesisir dihadapkan pada 
ancaman yang tinggi pula, maka hendaknya wilayah pesisir ditangani secara khusus agar wilayah ini dapat dikelola secara berkelanjutan.

Transisi antara daratan dan lautan di wilayah pesisir telah membentuk ekosistem yang beragam dan sangat produktif serta memberikan nilai ekonomi yang luar biasa terhadap manusia. Sejalan dengan pertambahan penduduk dan peningkatan kegiatan pembangunan sosial-ekonomi "nilai" wilayah pesisir terus bertambah. Konsekuensi dari tekanan terhadap pesisir ini adalah masalah pengelolaan yang timbul karena konflik pemanfaatan yang timbul akibat berbagai kepentingan yang ada di wilayah pesisir.

Sebagai wilayah peralihan darat dan laut yang memiliki keunikan ekosistem, dunia memiliki kepedulian terhadap wilayah ini, khususnya di bidang lingkungan dalam konteks pembangunan berkelanjutan (sustainable development). Secara historis, kota-kota penting dunia bertempat tidak jauh dari laut. Alasannya, kawasan ini memiliki potensi sumber daya kelautan dan perikanan, serta memudahkan terjadinya perdagangan antar daerah, pulau dan benua. Selain itu, wilayah pesisir juga merupakan daerah penghambat masuknya gelombang besar air laut ke darat, yaitu dengan keberadaan hutan mangrove.

Pantai merupakan salah satu kawasan hunian atau tempat tinggal paling penting di dunia bagi manusia dengan segala macam aktifitasnya. Awal tahun 1990 diperkirakan $50 \%$ sampai $70 \%$ penduduk di dunia tinggal di daerah pantai. Bila pada saat itu penduduk di dunia berjumlah kurang lebih 5,3 milyar maka 2,65 sampai 3,7 milyar tinggal di pantai.

Penduduk yang tinggal di daerah pantai pada era 1990 adalah sama dengan seluruh penduduk dunia pada tahun 1950-an (Gunther dkk., 1993). Dalam dua puluh tahun ke depan penduduk di daerah ini akan meningkat (NOAa, 1994) yaitu bahwa sampai tahun 2020, tiga perempat $(75 \%)$ penduduk dunia di prediksi tinggal di dalam kawasan garis pantai sampai sejauh $60 \mathrm{~km}$ ke daratan.

Menurut para ahli, panjang pantai di Indonesia kurang lebih $81.000 \mathrm{~km}$ dan merupakan pantai terpanjang di dunia setelah pantai di Kanada. Dengan jumlah pulau mencapai 17.500, maka persoalan pantai di Indonesia menjadi topik yang sangat penting untuk pengembangan dan pembangunan di Indonesia, termasuk sebagian di Kota Sorong. Pantai adalah jalur yang merupakan pertemuan antara darat dan laut. Daerah pantai ini mempunyai ciri geosfer yang khusus, ke arah laut dibatasi oleh pengaruh fisik laut dan sosial ekonomi bahari, sedangkan ke arah darat dibatasi oleh pengaruh proses alami dan kegiatan manusia terhadap lingkungan darat.

Luas daratan Indonesia mencapai 1,9 juta $\mathrm{km}^{2}$ dan luas perairan laut kurang lebih 7,9 juta $\mathrm{km}^{2}$. Sebanyak 22 persen dari total penduduk Indonesia mendiami wilayah pesisir. Ini berarti 
bahwa daerah pesisir merupakan salah satu pusat kegiatan ekonomi nasional melalui kegiatan masyarakat seperti perikanan laut, perdagangan, budidaya perikanan (aquakultur), transportasi, pariwisata, pengeboran minyak dan sebagainya. Seperti diketahui bahwa secara biologis wilayah pesisir merupakan lingkungan bahari yang paling produktif dengan sumber daya maritim utamanya seperti hutan bakau (mangrove), terumbu karang (coral reefs), padang lamun (sea grass beds), estuaria, daerah pasang surut dan laut lepas serta sumber daya yang tak dapat diperbaharui lainnya seperti minyak bumi dan gas alam.

Wilayah pesisir adalah suatu wilayah peralihan antara daratan dan lautan dimana batasnya dapat didefinisikan baik dalam konteks struktur administrasi pemerintah maupun secara ekologis. Batas ke arah darat dari wilayah pesisir mencakup batas administratif seluruh desa (sesuai dengan ketentuan Direktorat Jenderal Pemerintahan Umum dan otonomi Daerah, Depdagri) yang termasuk dalam wilayah pesisir menurut Program Evaluasi Sumber Daya Kelautan (MERP). Sementara batas wilayah ke arah laut suatu wilayah pesisir untuk keperluan praktis dalam proyek MERP adalah sesuai dengan batas laut yang terdapat dalam peta Lingkungan Pantai Indonesia (LPI) dengan skala 1:50.000 yang diterbitkan oleh Badan Koordinasi Survei dan Pemetaan Nasional.

Sebagai negara kepulauan, laut dan wilayah pesisir memiliki nilai strategis dengan berbagai keunggulan komparatif dan kompetitif yang dimilikinya sehingga berpotensi menjadi prime mover pengembangan wilayah nasional. Bahkan secara historis menunjukkan bahwa wilayah pesisir ini telah berfungsi sebagai pusat kegiatan masyarakat karena berbagai keunggulan fisik dan geografis yang dimilikinya. Agar pemanfaatan sumber daya laut dan pesisir dapat terselenggara secara optimal, diperlukan upaya penataan ruang sebagai salah satu bentuk intervensi kebijakan dan penanganan khusus dari pemerintah dengan memperhatikan kepentingan stakeholders lainnya. Selain itu, implementasi penataan ruang perlu didukung oleh program-program sektoral baik yang terselenggarakan oleh Pemerintah Pusat, Pemerintah Daerah dan masyarakat termasuk dunia usaha.

Aspek yang paling sensitif terhadap dampak era yang serba industri seperti sekarang ini adalah lingkungan. Besar kecilnya kegiatan manusia pasti akan berdampak pada kualitas lingkungan. Dengan demikian, manusia sebagai pelaku utama lingkungan harus senantiasa mengendalikan dan menjaga lingkungan agar tidak mengalami kerusakan.

Di Indonesia, masalah lingkungan merupakan masalah yang cukup serius yang harus segera diatasi. Lingkungan hidup Indonesia yang dulu dikenal sangat ramah dan hijau kini seakan berubah menjadi ancaaman bagi masyarakatnya. Betapa tidak, tingkat kerusakan 
lingkungan di indonesia sangat besar. Pencemaran lingkungan dan aktifitas penebangan hutan secara illegal merupakan penyebab utamanya.

Banyaknya bencana yang sering terjadi di tanah air seperti banjir dan tanah longsor merupakan bukti betapa pentingnya menjaga kelestarian lingkungan di era globalisasi. Kesadaran untuk hidup lebih baik harus senantiasa dipegang oleh manusia khusunya yang tinggal di kota-kota besar karena manusialah penyebab utama terjadinya bencana tersebut. Tanpa manusia sadari, ketika membuang sampah di sembarang tempat, menebang pohon tanpa perencanaan adalah suatu aktifitas yang membahayakan kehidupannya.

Tingkat eksploitasi dan konsumsi energi fosil yang terlalu berlebihan selama beberapa dekat ke belakang serta pengrusakan hutan dan rendahnya usaha konservasi lahan menyebabkan terjadinya berbagai masalah lingkungan yang parah di Indonesia. Masalah lingkungan yang terjadi diantarannya global warming, polusi dan pencemaran lingkungan. Semua masalah itu berujung pada terjadinya degradasi lingkungan yang mengancam aktifitas kehidupan manusia. Lingkungan yang terdegradasi tidak mampu lagi menyokong aktifitas kehidupan manusia dengan baik.

Wilayah pesisir yang kaya aneka ragam hayati, perlu diatur mengenai kebijakannya yang harus sustainable, penyelenggaraan penataan ruang tersebut tentunya harus memperhatikan kondisi geografis, sosial budaya seperti demografi, sebaran penduduk, serta aspek potensial dan strategis lainnya. Hasil dari penyelenggaraan penataan ruang ini diharapkan dapat mewujudkan pembangunan berkelanjutan (Sustainable Development) yang dapat memadukan pilar ekonomi, sosial budaya, lingkungan dan pemerataan pembangunan.

Aspek keberlanjutan dalam suatu pembangunan itu penting, maka diperlukan adanya kebijakan yang tepat dalam suatu wilayah. Dalam UU No. 32/2009 tentang Perlindungan dan Pengelolaan Lingkungan Hidup Pasal 1 Butir 10 Kajian Lingkungan Hidup Strategis (KLHS) adalah rangkaian analisis yang sistematis, menyeluruh dan partisipatif untuk memastikan bahwa prinsip pembangunan berkelanjutan telah menjadi dasar dan terintegrasi dalam pembangunan suatu wilayah dan atau kebijakan, rencana dan atau program. Namun seringkali terjadi pelanggaran pada daerah kawasan pesisir Pantai Kota Sorong, pada daerah ini kerap kali terjadi penyimpangan berupa eksploitasi sumber daya alam yang dilakukan oleh masyarakat sekitar untuk memenuhi kebutuhan hidupnya. Jika hal tersebut terus dilakukan dan tidak ada upaya penanganan yang serius dari pihak pemerintah, maka dikhawatirkan akan terjadi kelangkaan sumber daya hayati di kawasan pesisir tersebut. Serta akan terjadi konflik yang tak terkendali di kalangan masyarakat itu sendiri karena memiliki kepentingan sendiri-sendiri. 
Dengan diberlakukannya UU No. 32 Tahun 2004 tentang Pemerintah Daerah, maka menjadikan landasan hukum bagi daerah untuk mengembangkan daerahnya sendiri dengan kata lain pemerintah pusat memberikan kewenangan terhadap pemerintah daerah untuk mengatur dan mengurus rumah tangganya sendiri.

Oleh karena hal-hal tersebut diatas, maka perlu diuraikan beberapa upaya pengelolaan dan kebijakan-kebijakan lingkungan hidup di daerah pesisir Kota Sorong dan berharap dengan hadirnya penelitian ini dapat memberikan pengetahuan tentang pentingnya lingkungan.

Adapun yang menjadi masalah dalam penelitian ini adalah.; (1) Bagaimanakah peran pemerintah dalam menanggulangi kerusakan lingkugan pada daerah pesisir Kota Sorong?; (2) Bagaimana Upaya pemerintah dalam menanggulangi kerusakan lingkugan pada daerah pesisir Kota Sorong?

\section{PEMBAHASAN}

\section{Kondisi Daerah Pesisir Kota Sorong}

Pesisir merupakan daerah pertemuan antara darat dan laut; ke arah darat meliputi bagian daratan, baik kering maupun terendam air, yang masih dipengaruhi sifat-sifat laut seperti pasang surut, angin laut, dan perembesan air asin; sedangkan ke arah laut meliputi bagian laut yang masih dipengaruhi oleh proses-proses alami yang terjadi di darat seperti sedimentasi dan aliran air tawar, maupun yang disebabkan oleh kegiatan manusia di darat seperti penggundulan hutan dan pencemaran

Berdasarkan Keputusan Menteri Kelautan dan Perikanan tentang Pedoman Umum Perencanaan Pengelolaan Pesisir Terpadu, wilayah pesisir didefinisikan sebagai wilayah peralihan antara ekosistem darat dan laut yang saling berinteraksi, dimana ke arah laut 12 mil dari garis pantai untuk propinsi dan sepertiga dari wilayah laut itu (kewenangan propinsi) untuk kabupaten/kota dan ke arah darat batas administrasi kabupaten/kota.

Luas wilayah Kota Sorong adalah sebesar $110.500 \mathrm{Ha}(1.105 \mathrm{~km})$, pola penggunaan lahan yang ada terbentuk oleh aktivitas kota atau dalam pengertian lain dominasi kegiatan akan membentuk pola pemanfaatan ruangnya. Penggunaan lahan di Kota Sorong manurut jenis kegiatannya meliputi berbagai jenis kegiatan yang disesuaikan dengan kondisi geografisnya yang secara umum terdiri atas perumahan, perkantoran, fasilitas pendidikan, fasilitas kesehatan, fasilitas peribadatan, fasilitas sosial ekonomi, hutan dan lahan kosong. 
Saat ini, terlihat adanya gejala perkembangan fisik kota. Perkembangan ini dipicu oleh dua hal pokok, yaitu bertambahnya jumlah penduduk kota di satu sisi dan bertambahnya volume dan frekuensi kegiatan penduduk di sisi lain. Meningkatnya jumlah penduduk dan meningkatnya kegiatan di daerah perkotaan telah mengakibatkan tuntutan akan ruang yang besar pula. Meningkatnya jumlah penduduk selalu bersamaan dengan meningkatnya tuntutan akan ruang untuk permukiman, sedangkan meningkatnya kegiatan selalu diikuti oleh meningkatnya tuntutan akan ruang untuk mengakomodasikan prasarana fisik kegiatan yang bersangkutan. Pola penggunaan lahan terbangun dan non-terbangun adalah sebagai berikut.

Lahan Terbangun:

- Kawasan Pemukiman

- Kawasan Perdagangan/Jasa

- Kawasan Industri

- Kawasan Wisata

- Fasilitas Umum dan Sosial
Lahan non-terbangun:

- Kawasan Hutan

- Kawasan Perkebunan/Ladang

- Kawasan Rawa 
Tutupan lahan Kota Sorong hasil analisis Citra Alos tahun 2012 menjelaskan bahwa luas lahan terbangun di Kota Sorong adalah seluas 2697 hektar atau seluas 7.6 persen dari seluruh tutupan lahan yang ada. Lahan terbangun ini yang di golongkan kedalam Kawasan Bandara, Industri, Pelabuhan, Kompleks TNI/Polri, Pemukiman. Sementara untuk luasan lahan non-terbangun adalah seluas 32.408 hektar atau berkisar 92.4 persen yang tergolong kedaam ; Dana, Hutan Primer, Hutan Sekunder, Hutan Wisata, Lahan Kosong, Mangrove, Pertanian Lahan kering, Rawa, Semak belukar, Sungai, Tambak dan Tegalan.

Tabel 8. Tutupan lahan Kota Sorong tahun 2012

\begin{tabular}{|c|l|r|r|l|r|}
\hline No & Tutupan Lahan & \multicolumn{1}{l|}{ Luas } & No & Tutupan Lahan & Luas \\
\hline 1 & Danau & 0, & 10 & Mangrove & $1.379,6$ \\
\hline 2 & Hutan Primer & 13.059, & 11 & Pemukiman & $2.457,8$ \\
\hline 3 & Hutan Sekunder & $12.914,51$ & 12 & Pertanian Lahan & $3.321,61$ \\
& & & V.a. & 6,4 \\
\hline 4 & Hutan Wisata & 105, & 13 & Rawa & 768,6 \\
\hline 5 & Kawasan Bandara & 95, & 14 & Semak Belukar & 148,0 \\
\hline 6 & Kawasan Industri & 6, & 15 & Semak/Belukar & 98,0 \\
\hline 7 & Kawasan Pelabuhan & 59, & 16 & Sungai & 87,4 \\
\hline 8 & Kompleks TNI/Polri & 39, & 17 & Tambak & 511,7 \\
\hline 9 & Lahan Kosong & 47, & 18 & Tegalan & $\mathbf{3 5 . 1 0 6 , 9}$ \\
\hline & Jumlah & \multicolumn{3}{l}{} & \\
\hline
\end{tabular}

Sumber: Analisis GIS Kota Sorong (2012 
Wilayah pesisir adalah wilayah pertemuan antara daratan dan laut, ke arah darat meliputi bagian daratan yang masih dipengaruhi oleh sifat-sifat laut seperti pasang surut, angin laut dan intrusi garam, sedangkan ke arah laut mencakup bagian laut yang masih dipengaruhi oleh proses alami yang ada di darat seperti sedimentasi dan aliran air tawar serta daerah yang dipengaruhi oleh kegiatan-kegiatan manusia di daratan. Hal ini menunjukkan bahwa tidak ada garis batas yang nyata, sehingga batas wilayah pesisir hanyalah garis khayal yang letaknya ditentukan oleh situasi dan kondisi setempat.

Dari definisi wilayah pesisir tersebut secara umum memberikan gambaran besar, betapa kompleksitas aktivitas ekonomi dan ekologi yang terjadi di wilayah ini. Kompleksitas aktivitas ekonomi seperti perikanan, pariwisata, pemukiman, perhubungan, dan sebagainya memberikan tekanan yang cukup besar terhadap keberlanjutan ekologi wilayah pesisir seperti ekosistem mangrove, padang lamun dan terumbu karang. Tekanan yang demikian besar tersebut jika tidak dikelola secara baik akan menurunkan kualitas dan kuantitas sumberdaya yang terdapat di wilayah pesisir.

Provinsi Papua Barat khususnya Kota Sorong merupakan salah satu daerah di Indonesia yang memiliki potensi pesisir dan kelautan yang sangat besar. Garis pantainya yang memiliki banyak potensi pesisir dan kelautan yang bisa dimanfaatkan. Keberadaan terumbu karang, hutan mangrove, serta keanekaragaman flora dan fauna laut merupakan potensi yang memiliki nilai ekonomi yang menjanjikan, baik di bidang produksi maupun di bidang pariwisata. Saat ini ekosistem pantai terancam kelestariannya terutama oleh kegiatan manusia. Sumber daya pantai merupakan anugerah alam yang sangat berharga bagi mahluk hidup yang perlu dikelola dan dikembangkan secara baik untuk kepentingan saat ini dan dimasa yang akan datang. Untuk tetap menjaga potensi sumber daya pesisir Kota sorong, maka diperlukan suatu pengelolaan yang dilakukan secara terpadu dan berkesinambungan agar sumber daya yang ada tersebut tetap terjaga.

Wilayah pesisir yang kaya aneka ragam hayati, perlu diatur mengenai kebijakannya yang harus sustainable, penyelenggaraan penataan ruang tersebut tentunya harus memperhatikan kondisi geografis, sosial budaya seperti demografi, sebaran penduduk, serta aspek potensial dan strategis lainnya. Hasil dari penyelenggaraan penataan ruang ini diharapkan dapat mewujudkan pembangunan berkelanjutan (Sustainable Development) yang dapat memadukan pilar ekonomi, sosial budaya, lingkungan dan pemerataan pembangunan. 
Aspek keberlanjutan dalam suatu pembangunan itu penting, maka diperlukan adanya kebijakan yang tepat dalam suatu wilayah. Dalam UU No. 32/2009 tentang Perlindungan dan Pengelolaan Lingkungan Hidup Pasal 1 Butir 10 Kajian Lingkungan Hidup Strategis (KLHS) adalah rangkaian analisis yang sistematis, menyeluruh dan partisipatif untuk memastikan bahwa prinsip pembangunan berkelanjutan telah menjadi dasar dan terintegrasi dalam pembangunan suatu wilayah dan atau kebijakan, rencana dan atau program. Namun seringkali terjadi pelanggaran pada daerah kawasan pesisir Pantai Kota Sorong, pada daerah ini kerap kali terjadi penyimpangan berupa eksploitasi sumber daya alam yang dilakukan oleh masyarakat sekitar untuk memenuhi kebutuhan hidupnya. Jika hal tersebut terus dilakukan dan tidak ada upaya penanganan yang serius dari pihak pemerintah, maka dikhawatirkan akan terjadi kelangkaan sumber daya hayati di kawasan pesisir tersebut. Serta akan terjadi konflik yang tak terkendali di kalangan masyarakat itu sendiri karena memiliki kepentingan sendiri-sendiri.

Dengan diberlakukannya UU No. 32 Tahun 2004 yang telah diubah dengan UU No. 23 tahun 2014 tentang Pemerintah Daerah, maka menjadikan landasan hukum bagi daerah untuk mengembangkan daerahnya sendiri dengan kata lain pemerintah pusat memberikan kewenangan terhadap pemerintah daerah untuk mengatur dan mengurus rumah tangganya sendiri.

\section{Dasar-dasar Kebijaksanaan pengendalian Kerusakan Lingkungan Di Daerah Pesisir Kota}

\section{Sorong}

Undang-undang Dasar 1945 sebagai landasan konstitusional menegaskan bahwa sumberdaya alam agar dipergunakan untuk sebesar-besarnya kemakmuran rakyat, dan harus dapat dinikmati baik oleh generasi sekarang maupun generasi mendatang. Konsep pembangunan berkelanjutan yang telah diletakkan sebagai kebijaksanaan pada masa lalu, pada kenyataannya selama ini justru terjadi pengelolaan sumber daya alam yang tidak terkendali dengan akibat kerusakan lingkungan yang mengganggu kelestarian alam.

Kebijakan Agenda 21 Indonesia, dimana pengelolaan sumber daya alam merupakan agenda keempat. Tiga sub-agenda dirumuskan dalam agenda ini, yaitu: (1) konservasi keanekaragaman hayati; (2) pengembangan bioteknologi; dan (3) pengelolaan terpadu wilayah pesisir dan lautan. Penanganan bagi ketiga aspek tersebut diarahkan pada upaya pelestarian dan perlindungan biologi pada tingkat genetic, spesies dan ekosistem, serta menjamin kekayaan alam, binatang dan tumbuhan di seluruh Indonesia. 
Pasal 65 ayat (1) Undang-undang Nomor 32 Tahun 2009 tentang Perlindungan dan Pengelolaan Lingkungan Hidup menyatakan: "Setiap orang berhak atas lingkungan hidup yang baik dan sehat sebagai bagian dari hak asasi manusia". Selain itu pada Pasal 67 Undang-Undang tersebut menyatakan:"Setiap orang berkewajiban memelihara kelestarian fungsi lingkungan hidup serta mengendalikan pencemaran dan/atau kerusakan lingkungan hidup". Hal ini berarti antara masyarakat dan pemerintah perlu menjalin hubungan yang baik dalam melestarikan lingkungan hidup. Dalam pengaturan sumber daya alam, fungsi pemerintah adalah; (1) mengatur dan mengembangkan kebijaksanaan dalam rangka pengelolaan lingkungan hidup; (2) mengatur penyediaan, peruntukan, penggunaan, pengelolaan lingkungan hidup, dan pemanfaatan kembali sumberdaya alam, termasuk sumberdaya genetika; (3) mengatur perbuatan hukum dan hubungan hukum antara orang dan/atau subyek hukum lainnya serta perbuatan hukum terhadap sumberdaya alam dan sumberdaya buatan, termasuk sumberdaya genetika; (4) mengendalikan kegiatan yang mempunyai dampak sosial; (5) mengembangkan pendanaan bagi upaya pelestarian fungsi lingkungan hidup sesuai peraturan perundang-undangan yang berlaku."

Sedangkan mengenai kebijaksanaan nasional lingkungan hidup mengacu pada nilai-nilai dasar dalam pelestarian lingkungan, yaitu sebagai berikut; (1) Pelestarian lingkungan dilaksanakan berdasarkan konsep Pembangunan Berkelanjutan, yaitu pembangunan yang mampu memenuhi aspirasi dan kebutuhan manusia pada generasi-generasi mendatang. Pembangunan Berkelanjutan didasarkan atas kesejahteraan masyarakat serta keadilan dalam jangka waktu pendek, menengah dan panjang dengan keseimbangan pertumbuhan ekonomi, dinamisme social dan pelestarian lingkungan hidup.; (2) Fungsi lingkungan perlu dilestarikan demi kepentingan manusia baik dalam jangka pendek, menengah, maupun jangka panjang. Pengambilan keputusan dalam pembangunan perlu memperhatikan pertimbangan daya dukung lingkungan sesuai fungsi lingkungannya. Daya dukung lingkungan menjadi kendala (constraint) dalam pengambilan keputusan dan prinsip ini perlu dilakukan secara kontinu dan konsekuen.; (3) Pemanfaatan sumber daya alam tak terpulihkan perlu memperhatikan kebutuhan antar generasi. Pemanfaatan sumber daya alam terpulihkan perlu mempertahankan daya pemulihannya.; (4) Setiap warga negara mempunyai hak untuk mendapatkan lingkungan yang baik dan sehat dan berkewajiban untuk melestarikan lingkungan. Oleh karenanya, setiap warga negara mempunyai hak untuk mendapatkan informasi lingkungan yang benar, lengkap dan mutahir.; (5) Dalam pelestarian lingkungan, usaha pencegahan lebih diutamakan daripada usaha penanggulangan dan pemulihan.; (6) Kualitas lingkungan ditetapkan 
berdasarkan fungsinya. Pencemaran dan perusakan lingkungan perlu dihindari; bila sampai terjadi pencemaran dan perusakan lingkungan, maka diadakan penanggulangan dan pemulihan dengan tanggung jawab pada pihak yang menyebabkan.; (7) Pelestarian lingkungan dilaksanakan berdasarkan prinsip-prinsip pelestarian melalui pendekatan menejemen yang layak dengan sistem pertanggungjawaban.

Undang-Undang Perlindungan dan Pengelolaan Lingkungan Hidup mengamanatkan pengelolaan lingkungan hidup dilaksanakan secara terpadu. Dalam Pasal 2 huruf d. dinyatakan "Perlindungan dan Pengelolaan lingkungan hidup dilaksanakan berdasarkan asas keterpaduan".

Berdasarkan hal tersebut di atas, maka pelaksanaan pengelolaan pesisir dan laut harus dilakukan secara terpadu. Keterpaduan ini meliputi keterpaduan antar sektor (permukiman, pariwisata, perhubungan, perikanan, kehutanan, industri dll.), keterpaduan tugas dan kewajiban serta keterpaduan antara aspek, yaitu sosial ekonomi, ekologi, teknologi dan kelembagaan (institusi).

Untuk melaksanakan kebijakan di bidang pengelolaan pesisir dan laut, Pemerintah Daerah telah diberikan kewenangan di wilayah laut. Pasal 18 Undang-Undang Nomor 32 tahun 2004 tentang Pemerintahan Daerah, memberikan kewenangan Pemerintah Daerah untuk mengelola sumber daya di wilayah laut meliputi; (1) eksplorasi, eksploitasi, konservasi, dan pengelolaan kekayaan laut; (2) pengaturan kepentingan administrative; (3) pengaturan tata ruang; (4) penegakan hukum terhadap peraturan yang dikeluarkan oleh daerah atau yang dilimpahkan kewenangannya oleh Pemerintah; (5) ikut serta dalam pemeliharaan keamanan dan; (6) ikut serta dalam pertahanan kedaulatan negara.

Kewenangan daerah yang tersebut di atas merupakan dasar dalam pengelolaan wilayah pesisir secara terpadu, dengan demikian daerah dapat memanfaatkan sumber daya alam yang ada diwilayahnya untuk meningkatkan pendapatan daerah. Kemudian dalam Pasal 18 ayat (4) UndangUndang Nomor 32 tahun 2004 tentang Pemerintahan Daerah, dinyatakan bahwa kewenangan untuk mengelola sumber daya di wilayah laut paling jauh 12 (dua belas) mill laut diukur dari garis pantai ke arah laut lepas dan/atau ke arah perairan kepulauan untuk provinsi dan 1/3 (sepertiga) dari wilayah kewenangan provinsi untuk kabupaten/kota.

Adanya kewenangan yang diberikan kepada pemerintah daerah sampai 12 mil, maka kegiatan pemantauan, pengawasan pengendalian, evaluasi dan pelaporan di wilayah pesisir dapat dilakukan secara rutin dan berkesinambungan. Pada Pasal 18 Ayat (3) huruf d. Undang-undang 
tentang Pemerintahan Daerah, dinyatakan bahwa kewenangan Daerah di wilayah laut termasuk penegakan hukum terhadap peraturan yang dikeluarkan oleh daerah atau yang dilimpahkan kewenangannya oleh pemerintah. Hal ini memungkinkan Pemerintah Daerah untuk mengeluarkan Peraturan Daerah yang berkaitan dengan pengelolaan pesisir dan laut, sehingga pemahaman atas konvensi internasional yang telah diratifikasi oleh Pemerintah Indonesia menjadi sangat penting agar tidak terjadi kerancuan hukum. Adanya wewenang melakukan penegakan hukum di wilayah laut juga dapat mendorong diadakannya Penyidik Pegawai Negeri Sipil Lingkungan Hidup, sehingga langkah penegakan hukum dapat lebih lancar.

\section{Peran Pemerintah Dalam Menanggulangi Kerusakan Lingkungan Hidup Di Daerah Pesisir Kota Sorong}

Peranan pemerintah, swasta dan masyarakat dalam hal ini menjadi bagian terpenting yang tidak terpisahkan dalam upaya mengelola lingkungan pesisir dan laut. Dewasa ini, pengelolaan lingkungan secara terpadu dimungkinkan untuk memberikan peluang pengelolaan yang cukup efektif dalam rangka menyeimbangkan antara pelestarian lingkungan dan pemanfaatan ekonomi. Namun demikian, hal ini tidak menutup kemungkinan akan adanya bentuk-bentuk pengelolaan lain yang lebih aplikatif (applicable) dan adaptif (acceptable). Salah satu bentuk pengelolaan yang cukup berpeluang memberikan jaminan efektifitas dalam pengimplementasiannya adalah pengelolaan berbasis masyarakat (community based management).

Proses pengelolaan lingkungan ada baiknya dilakukan dengan lebih memandang situasi dan kondisi lokal agar pendekatan pengelolaannya dapat disesuaikan dengan kondisi lokal daerah yang akan dikelola. Pandangan ini tampaknya relevan untuk dilaksanakan di Indonesia dengan cara memperhatikan kondisi masyarakat dan kebudayaan serta unsur-unsur fisik masing-masing wilayah yang mungkin memiliki perbedaan disamping kesamaan. Dengan demikian, strategi pengelolaan pada masing-masing wilayah akan bervariasi sesuai dengan situasi setempat. Yang perlu diperhatikan adalah nilai-nilai dan norma-norma yang dianut oleh suatu masyarakat yang merupakan kearifan masyarakat dalam pengelolaan sumberdaya alam dan lingkungan.

Segenap gambaran wacana tersebut di atas secara umum memberikan cermin bagaimana sebuah pengelolaan yang melibatkan unsur masyarakat cukup penting untuk dikaji dan diujicobakan. Peran serta masyarakat dalam pengelolaan ini lebih dikenal dengan istilah pengelolaan berbasis masyarakat (PBM) atau community based management (CBM). 
Peran Pemerintah Kota Sorong dalam Pelestarian Lingkungan Pesisr antara lain:(1) Pembuatan Tanggul Pesisir, Dusun Bajo yang terletak di daerah pesisir yang berbatasan dengan selat Alas tidak bisa dilepaskan dari permasalahan abrasi pantai. Abrasi pantai yang merupakan proses pengikisan pantai yang dikarenakan kekuatan gelombang laut dan arus laut yang kuat dan bersifat merusak, kerusakan atau abrasi pantai disebabkan oleh gejala alami dan ulah tangan manusia Pada dasarnya dampak yang terjadi akibat proses abrasi pantai tidak dapat dihindari, namun prosesnya saja yang lama dan ada atau tidaknya pemicu yang dapat mempercepatnya. Dampak yang ditimbulkan dari abrasi pantai diantaranya adalah kerusakan ekosistem terumbu karang, hutan mangrove secara alami, akibat pengikisan yang terjadi secara terus-menerus. Kemudian, terjadi penurunan keanekaragaman organisme disekitarnya akibat ekosistem dimana organisme tersebut lahir, tumbuh, mencari makan dan hidup, rusak dan hilangnya tempat berkumpulnya ikan ikan perairan pantai karena terkikisnya hutan bakau.

Dampak abrasi pantai lainnya juga akan sangat terlihat pada bibir pantai, dimana garis pantai akan semakin bergeser ke arah daratan, yang berarti akan terjadi penyempitan lahan tempat tinggal bagi penduduk sekitar pantai, apabila tidak diatasi lama kelamaan daerah-daerah yang permukaannya rendah akan tenggelam. Selain itu pantai yang indah dan menjadi tujuan wisata menjadi rusak.

Namun abrasi pantai di Kota Sorong sudah bisa dicegah dengan membuat tanggul di sekitar wilayah pesisir Bandara Deo. Pembangunan tanggul di wilayah pesisir Bandara Deo Kota Sorong di mulai sejak bulan juni 2013 dan rampung pada bulan november 2013. Proyek Pemerintah Pusat pembangunan dinding laut pantai Kota Sorong. Pembangunan tanggul sepanjang 525 meter ini dibiayai APBN . Kondisi tanggul penahan ombak di Kawasan Pesisir Bandara Deo Kota Sorong saat ini sudah berjalan dengan baik. Warga pesisir sudah terlindungi dari ancaman gelombang pasang dan abrasi yang sebelumnya melanda wilayah pesisir di Kawasan Pesisir Bandara Deo Kota Sorong,; (2) Penanaman Vegetasi Mangrove, Mangrove mempunyai peranan ekologis, ekonomis, dan sosial yang sangat penting dalam mendukung pembangunan wilayah pesisir. Kerja sama pemerintah daerah dengan masyarakat wilayah pesisir Kota Sorong sudah pernah dilakukan seperti kegiatan penghijauan yang di naungi oleh Badan Linkungan Hidup dan Dinas Kehutanan pada tahun 2015 dengan menyediakan bibit mangrove sekitar 1000 pohon untuk ditanam di wilyah pesisir Kota Sorong Berdasarkan hasil observasi yang dilakukan oleh peneliti, hutan mangrove yang berada di kawasan Pesisir Kota Sorong saat ini mengalami kerusakan karena 
kawasan mangrove beralih menjadi tambak ikan dan udang, selain itu juga di karenakan adanya eksploitasi (penebangan) tumbuhan mangrove untuk dijadikan kayu bakar oleh masyarakat disekitar pesisir.

"Kita memang belum memiliki data real seberapa besar lahan hutan magrove yang beralih fungsi menjadi tambak ikan atau udang, tetapi apabila melihat kondisinya sekarang bisa dipastikan sudah sangat banyak lahan mangrove yang beralih fungsi. Kita beberapa kali mengadakan program penanaman kembali tanaman mangrove tapi hasilnya sungguh mengecewakan, dari 1000 tanaman mangrove yang kita tanam hanya bersisa setengahnya jangka. Banyak dari masyarakat sekitar yang bukannya turut menjaga keberlangsungan tanaman magrove malah di tebang. Mungkin mereka mengira hutan magrove itu kurang penting...."kata Tatang Sekretaris Badan Lingkungan Hidup" Upaya Pemerintah Dalam Penanggulanagn Kerusakan Lingkungan Di Daerah Pesisir Kota Sorong

Wilayah pesisir pantai memiliki potensi yang tak ternilai bagi masyarakat. Perairan pantai tidak saja menjadi sumber pangan yang produktif, tetapi juga sebagai gudang mineral, alur pelayaran, tempat rekreasi dan juga sebagai tangki pencerna bahan buangan hasil kegiatan manusia. Besarnya sumber alam yang terkandung di dalamnya, hayati maupun non hayati serta aneka kegunaan yang bersifat ganda merupakan bukti yang tidak dapat disangkal, bahkan menjadi tumpuan harapan manusia dalam usahanya memenuhi kebutuhan pangan yang terus meningkat di masa mendatang.

Berdasarkan hasil observasi yang telah dilakukan Keadaan wilayah pesisir Kota Sorong cukup memprihatinkan karna adanya peningkatan kegiatan yang mengkonversi kawasan daerah pesisir menjadi peruntukan lain yaitu pembukaan lahan tambak, selain itu juga dikarenakan adanya eksploitasi (penebangan) tumbuhan mangrove untuk dijadikan kayu bakar oleh masyarakat sekitar kawasan daerah pesisir.

Perubahan kawasan mangrove menjadi lahan tambak ikan dan udang oleh masyarakat sebenarnya bukan karena tidak ada alasan, hal ini disebabkan karena hasil tangkapan ikan di laut sudah sangat berkurang sehingga biaya yang mereka keluarkan untuk pergi melaut terkadang lebih besar dari pada hasil tangkapan. Selain itu juga terkena pencemaran lingkungan. Hal ini terlihat dari banyaknya sampah yang menggenang baik yang berada di kawasan pemukiman penduduk dan sekitar wilayah pesisir. Bukan itu saja sampah-sampah sisa aktivitas ekonomi, sampah rumah tangga dan tumpahan bahan bakar minyak dari kapal-kapal yang berlabuh di wilayah pesisir Kota Sorong

Upaya-upaya yang dilakukan oleh pemerintah daerah Kota Sorong; (1) Penataan lingkungan berupa perbaikan rumah tidak layak huni.; (2) Penanaman pohon mangrove merupakan 
salah satu upaya Pemerintah Daerah (Pemda) Kota Sorong, dirangkaikan dengan penanaman pohon penghijauan di sekitar pantai.; (3) Penyuluhan hukum terhadap masyarakat kawasan daerah pesisir Kota Sorong di maksudkan untuk memeberikan pengetahuan terhadap para masyarakat setempat tentang peraturan perundang-undagan yang berkaitan dengan kelautan dan perikanan.

\section{SIMPULAN}

Berdasarkan hasil penelitian diatas maka diperoleh beberapa kesimpulan antara lain adalah : (A) Peran Pemerintah Kota Sorong dalam Pelestarian Lingkungan Pesisr antara lain; (1) Pembuatan Tanggul Pesisir Pembuatan tanggul di sekitar wilayah pesisir Bandara Deo. Pembangunan tanggul di wilayah pesisir Bandara Deo Kota Sorong di mulai sejak bulan juni 2013 dan rampung pada bulan november 2013. Proyek Pemerintah Pusat pembangunan dinding laut pantai Kota Sorong. Pembangunan tanggul sepanjang 525 meter ini dibiayai APBN . Kondisi tanggul penahan ombak di Kawasan Pesisir Bandara Deo Kota Sorong saat ini sudah berjalan dengan baik. Warga pesisir sudah terlindungi dari ancaman gelombang pasang dan abrasi yang sebelumnya melanda wilayah pesisir di Kawasan Pesisir Bandara Deo Kota Sorong,; (2) Penanaman Vegetasi Mangrove Pemerintah melaksanakan kegiatan penghijauan yang di naungi oleh Badan Linkungan Hidup dan Dinas Kehutanan pada tahun 2015 dengan menyediakan bibit mangrove sekitar 1000 pohon untuk ditanam di wilyah pesisir Kota Sorong,; (B) Upaya-upaya yang dilakukan oleh pemerintah daerah Kota Sorong : (a) Penataan lingkungan berupa perbaikan rumah tidak layak huni,; (b) Penanaman pohon mangrove merupakan salah satu upaya Pemerintah Daerah (Pemda) Kota Sorong, dirangkaikan dengan penanaman pohon penghijauan di sekitar pantai.; (c) Penyuluhan hukum terhadap masyarakat kawasan daerah pesisir Kota Sorong di maksudkan untuk memeberikan pengetahuan terhadap para masyarakat setempat tentang peraturan perundang-undagan yang berkaitan dengan kelautan dan perikanan.

\section{DAFTAR PUSTAKA}

Beatley, T., Brower, D. J., \& Schwab, A. K. (2002). An Introduction to Coastal Zone Management (Second Edition). Washington DC: Island Press.

Dahuri, R. et al, 1996. Pengelolaan Sumberdaya Pesisir dan Lautan Secara Terpadu. PT. Pramadya Paramita, Jakarta.

Edgren G 1993 Expected economic and demographic development in coastal worl wide National Institute For coastal and Marine Management, Coastal Zone Management Centre Noordwijk, Netherland. 
Muttaqiena, dkk. 2009. Makalah Pengelolaan Wilayah Pesisir Secara Berkelanjutan Pasca Tsunami Desember 2004.

Menteri Permukiman Dan Prasarana Wilayah, 2003. Tinjauan Aspek Penataan Ruang Dalam Pengelolaan Wilayah Laut Dan Pesisir. Surabaya

Nurmala, Tati. 2012. Pengantar Ilmu Pertanian.Graha Ilmu. Yogyakarta

Nurmalasari. (2001). Pengaruh Penggunaan Media Benda Asli terhadap Prestasi Belajar Biologi Siswa Kelas 1 di SLTP N Yogyakarta tahun ajaran 2000/2001. Skripsi. UNY, Yogyakarta.

Soerjono, 2002, Teori Peranan, Jakarta, Bumi Aksara

Sondang P. Siagian, 2001, Manajemen Sumber Daya Manusia, Bumi Aksara, Jakarta

Syafiie, Inu Kencana. (2001). Pengantar Ilmu Pemerintahan. Bandung: Refika Aditama

Supriharyono. 2007. Konservasi Ekosistem Sumber Daya Hayati. Pustaka Pelajar. Yogyakarta:

Yuwono, Nur. 1992. Dasar-Dasar Perencanaan Bangunan Pantai Volume II. Yogyakarta: Biro Penerbit Keluarga Mahasiswa Teknik Sipil Fakultas Teknik UGM. 